\title{
Dinamika Sosial Budaya Masyarakat Desa Rappolemba Kecamatan Tompobulu Kabupaten Gowa (Studi Solidaritas Petani Cengkeh)
}

\author{
Haniah 1, Muhammad Iqbal Putra ${ }^{2}$ \\ ${ }_{1}^{1}$ Pendidikan Sosiologi, Universitas Muhammadiyah Makassar \\ Email : dr.hania968@gmail.com \\ ${ }_{1}^{1}$ Pendidikan Sosiologi, Universitas Muhammadiyah Makassar \\ Email : miqbalputra16@gmail.com
}

\begin{abstract}
This research aims to (1) To find out the social and cultural dynamics of clove farmers in Rappolemba Village, Tompobulu District, Gowa Regency. (2) To find out the impact of changes in social solidarity of clove farmers in Rappolemba Village, Tompobulu District, Gowa Regency. This type of research is descriptive qualitative. This research is located in Rappolemba Village, Tompobulu District, Gowa Regency. The informants in this study consisted of seven people namely the village head, four clove farmers and two residents. Data collection in this study uses observation, interview, and documentation techniques. While the data analysis in this study consists of three activities, namely data reduction, data presentation, and drawing conclusions. The results of this study are the fading of the mutual cooperation system in Rappolemba Village, Tompobulu Subdistrict due to the ineffective participation of village communities, especially clove farmers in mutual cooperation, causing the habit of helping by farmers and surrounding communities to switch to an individualistic way. The implementation of a wage system reduces the level of solidarity in society where the value of cooperation can be replaced by something of value. The existence of a wage system is considered to be more profitable so that gradually it starts to fade the culture of mutual cooperation that relies on cooperation without compensation. The positive impact of the implementation of the wage system provides little work for village girls who need work or for those who have no work at all. In addition, the existence of these wages also helps in fulfilling the economic compliance of workers or clove laborers. The negative impact of the existence of the wage system is the value of togetherness and habits that have been intertwined with the community began to decrease so they began to leave their traditions, namely mutual cooperation.
\end{abstract}

Keywords : Social Solidarity, Mutual Assistance System, Wage System

\begin{abstract}
Abstrak
Penelitian ini bertujuan untuk (1) Untuk mengetahui dinamika sosial budaya para petani cengkeh di Desa Rappolemba Kecamatan Tompobulu Kabupaten Gowa. (2) Untuk mengetahui dampak dari perubahan solidaritas sosial petani cengkeh di Desa Rappolemba Kecamatan Tompobulu Kabupaten Gowa. Jenis penelitian ini adalah kualitatif deskriptif. Penelitian ini berlokasi di Desa Rappolemba Kecamatan Tompobulu Kabupaten Gowa. Informan dalam penelitian ini terdiri dari tujuh orang yakitu Kepala desa, empat orang petani cengkeh dan dua warga. Pengumpulan data dalam penelitian ini menggunakan teknik observasi, wawancara, dan dokumentasi. Sementara analisis data dalam penelitian ini terdiri atas tiga alur kegiatan yaitu reduksi data, penyajian data, dan penarikan kesimpulan. Adapun hasil dari penelitian ini adalah Pudarnya sistem gotong royong di Desa Rappolemba Kecamatan Tompobulu dikarenakan kurang efektifnya keikutsertaan masyarakat desa khususnya petani cengkeh dalam bergotong royong sehingga menyebabkan kebiasaan bantu membantu oleh para petani dan masyarakat sekitar beralih ke cara yang individualis. Adanya penerapan sistem upah mengurangi tingkat solidaritas dalam masyarakat dimana nilai kerjasama bisa diganti dengan sesuatu yang bernilai. Adanya sistem upah dianggap lebih menguntungkan sehingga lambat laun hal tersebut mulai memudarkan kebudayaan gotong royong yang mengandalkan kerjasama tanpa imbalan. Adapun dampak positif dengan adanya penerapan sistem upah memberikan sedikit pekerjaan bagi pemud-pemudi desa yang memerlukan pekerjaan atau bagi mereka yang tidak memiliki pekerjaan sama sekali. Selain itu dengan adanya upah tersebut juga ikut dalam membantu memenuhi ketuhan ekonomi para pekerja atau buruh cengkeh. Adapun dampak negative dari adanya sistem upah tersebut yaitu nilai kebersamaan dan kebiasaan yang selama ini terjalin dengan masyarakat mulai berkurang sehingga mereka mulai meninggalkan tradisi mereka yaitu gotong royong.
\end{abstract}

Kata Kunci : Solidaritas Sosial, Sistem Gotong Royong, Sistem Upah. 


\section{PENDAHULUAN}

Perkembangan tanaman cengkeh tidak terlepas dari partisipasi aktif masyarakat, khususnya masyarakat yang turut menentukan keberhasilan pembangunan pertanian di daerah pedesaan. Solidaritas bagi para petani cengkeh adalah rasa persatuan, rasa persaudaraan, gotong royong, tolongmenolong, membantu sesama yang merupakan sebuah kelaziman yang tetap ada dalam masyarakat. Solidaritas sosial dalam masyarakat yang terbangun karena dengan mata pencaharian yang sama yakni dalam bidang pertanian, merupakan sebuah kesetiakawanan yang merujuk pada kesamaan serta pengalaman yang sama. Solidaritas sosial masyarakat petani cengkeh di Desa Rappolemba merupakan solidaritas yang terbangun antara sesama petani dan didasari oleh humanisme serta besarnya tanggung jawab dalam kehidupan bersama seperti gotong royong, kekompakan dan saling tolong menolong merupakan bentuk aktualisasi dari solidaritas masyarakat yang tertuang dalam kehidupan para petani. Solidaritas sebagai sebuah kesatuan sosial yang berupa persatuan, baik dalam dunia kerja maupun di luar pekerjaan saling membantu dalam hal gotong royong maupun tolong menolong adalah hal yang penting dalam menjalin rasa persaudaraan diantara petani.

Dahulu masyarakat desa dikenal dengan sistem tolong menolong atau rasa solidaritasnya tinggi, sehingga dalam melakukan suatu perbuatan seperti bertani masyarakat tidak perlu menyewa orang lain, namun hanya meminta tolong kepada masyarakat, tetangga, maupun kelurga inti. Dalam keadaan yang sekarang ini masyarakat desa mengalami perubahan-perubahan yang menjadikan solidaritas masyarakat desa menjadi pudar, hal ini tentu adanya sebuah sebab. Pudarnya solidaritas yang terjadi pada masyarakat petani cengkeh, tentunya tidak terjadi begitu saja, namun telah dipengaruhi oleh beberapa faktor yang kemudian masyarakat desa mulai berubah, sehingga meninggalkan kebiasaan-kebiasan seperti gotong royong dan mengakibatkan lunturnya kebersamaan masyarakat sehingga terjadilah kepudaran solidaritas diantara sesama petani cengkeh menjadi masyarakat yang Individual.

Pergeseran yang kini terjadi dikarenakan dinamika kehidupan sosial yang terjadi tidak seharusnya mengubah konsep gotong royong sebagai budaya khas Indonesia. Hal ini menyebabkan bahwa dalam proses bercocok tanam, terjadi proses pergeseran dari cara pengarahan tenaga bantuan di luar rumah tangga dengan gotong royong ke cara dengan menyewa buruh. Salah satu perubahan sosial yang terjadi dalam struktur dan fungsi masyarakat yaitu lemahnya sikap gotong royong masyarakat karena timbulnya sikap individualis masyarakat akibat masuknya sistem kapitalisme pada masyarakat. Pada hakikatnya, Manusia memiliki dua kepentingan, yaitu kepentingan individu dan kepentingan bersama. Namun, faktanya masih terdapat dalam suatu masyarakat yang bersifat individual dengan memilih pekerjaannya daripada menyalurkan bantuan untuk kepentingan bersama. Sama halnya di Desa Rappolemba Kecamatan Tompobulu Kabupaten Gowa yang sudah mengalami pergeseran Kebudayaan dari sistem gotong royong ke sistem mempekerjakan buruh. Masyarakat Rappolemba harus menjaga hubungan sosial bila ingin terus bertahan hidup, apabila tidak berhubungan sosial maka mereka harus siap-siap disingkirkan, terlebih lagi dalam hubungan sosial untuk mempertahankan pengembangan pertanian Cengkeh. Perubahan masyarakat secara umum menyangkut perubahan-perubahan 
struktur, fungsi budaya dan perilaku masyarakat.

Adanya masalah yang timbul dari pergeseran nilai-nilai sosial budaya yang mengakibatkan pudarnya tingkat solidaritas sosial masyarakat di Desa Rappolemba Kecamatan Tompobulu Kabupaten Gowa, perlahan budaya gotong royong yang sering dilakukan oleh masyarakat Desa Rappolemba mulai memudar dan tergantikan oleh sistem upah di karenakan kebutuhan hidup yang semakin tinggi. Selain itu masyarakat lain yang tidak bekerja atau memiliki kebun cengkeh mereka ikut tertarik menjadi buruh tani dengan harapan adanya upah yang dihasilkan sebagai buruh maka akan ikut membantu memenuhi kebutuhan hidup sehari-hari.

\section{METODE PENELITIAN}

Penelitian ini adalah jenis penelitian kualitatif, meliputi rangkaian kegiatan yang sistematik untuk mendapatkan jawaban dari permasalahan yang diajukan. Jika dilihat dari jenis dan objek yang diteliti, penelitian ini mengkaji tentang dinamika sosial budaya masyarakat desa Rappolemba Kecamatan Tompobulu Kabupaten Gowa (Studi kasus solidaritas petani cengkeh). Penelitian ini akan di laksanakan selama kurang lebih dua bulan yakni bulan dari Bulan Juli sampai dengan Bulan September di Desa Rappolemba Kecamatan Tompobulu Kabupaten Gowa.

Hal-hal yang menjadi sasaran dalam penelitian ini adalah dinamika sosial budaya di Desa Rappolemba Kecamatan Tompobulu Kabupaten Gowa berdasarkan studi kasus solidaritas para petani cengkeh. Untuk mengetahui informasi dari beberapa resonden sebagai sampel dengan teknik purosive sampling (peneliti memilih sampel sendiri yang dianggap mampu memberikan informasi mengenai apa yang akan diteliti). Informan di pilih sebanyak 7 orang yang terdiri atas Kepala desa Rappolemba, petani cengkeh sebanyak 4 orang serta buruh dan sopir mobil yang dianggap mampu memberikan informasi mengenai dinamika sosial budaya masyarakat desa Rappolemba Kecamatan Tompobulu Kabupaten Gowa (Studi kasus solidaritas petani cengkeh). Penelitian ini akan di laksanakan selama kurang lebih dua bulan yakni bulan dari Bulan Juli sampai dengan Bulan September. Semakin banyak data yang di peroleh maka semakin bagus untuk hasil penelitian. Dalam penelitian mengenai dinamika sosial budaya masyarakat desa Rappolemba Kecamatan Tompobulu Kabupaten Gowa (Studi kasus solidaritas petani cengkeh) yakni studi pustaka, observasi langsung, wawancara, dan dokumentasi. Teknik analisis data yang digunakan peneliti adalah teknik analisis data kualitatif melalui analisis yaitu reduksi kata kemudian penyajian data yang tersusun dalam laporan tulisan yang dijelaskan bersifat naratif kemudian menarik kesimpulan akhir dalam penelitian.

\section{HASIL DAN PEMBAHASAN}

Setelah melakukan observasi, wawancara, dan dokumentasi di lapangan maka akan disajikan data-data yang diperoleh dari penelitian. Untuk lebih jelasnya dapat dilihat sebagai berikut :

\section{Dinamika Sosial Budaya Para Petani Cengkeh Di Lihat Dari Solidaritas Sosial di Desa Rappolemba Kecamatan Tompobulu Kabupaten Gowa}

\section{a. Pudarnya Sistem Gotong Royong}

Solidaritas sosial masyarakat petani cengkeh di Desa Rappolemba merupakan solidaritas yang terbangun antara sesama petani dan didasari oleh humanisme serta besarnya tanggung jawab dalam kehidupan bersama seperti gotong 
royong, kekompakan dan saling tolong menolong merupakan bentuk aktualisasi dari solidaritas masyarakat yang tertuang dalam kehidupan para petani. Akan tetapi, seiring dengan perkembangan zaman saat ini, telah terjadi beberapa perubahan. Perubahan juga berarti suatu peroses yang mengakibatkan keadaan sekarang berbeda dengan keadaan yang sebelumnya. Seperti yang diungkapkan diungkapkan oleh bapak Dg. Hasin (52 tahun) yang berprofesi sebagai petani cengkeh, ia mengungkapkan bahwa:

"Kalau sekarang sudah sangat jarang dilakukan dikarenakan rata-rata petani cengkeh sekarang sudah memakai jasa pekerja untuk membantu dalam memanen, menanam bibit dengan cara di upah dikarenakan sudah susah untuk mendapatkan tenaga gratis sebab masyrakat juga di tuntut akan kebutuhan ekonomi yang sekarang sudah semakin mahal". (Wawancara, 05 Agustus 2019).

Perilaku gotong royong merupakan suatu aset bangsa yang harus tetap dipelihara oleh masyarakat karena merupakan sebuah manifestasi budaya yang telah ada dalam berbagai sendi kehidupan bermasyarakat. Akan tetapi dengan kondisi masyarakat sekarang, pemeliharaan adat istiadat gotong royong sepertinya sulit terwujud. Hal ini dapat dilihat dari kondisi masyarakat desa yang mulai berkembang yang menjadikan keberadaan gotong royong mulai punah. Perkembangan masyarakat desa disebabkan karena saling mempengaruhinya masyarakat satu dengan masyarakat lain. Sehingga dengan keadaan tersebut, maka kebudayaaan lambat laun akan mengalami pergeseran seiring dengan perkembangan. Seperti yang diungkapkan oleh Dg. Baha (45 tahun) yang berprofesi sebagai petani cengkeh yang mengatakan bahwa:
"Kalau sistem gotong royong kalau dahulu sangat terjalin dengan baik dimana kita saling membantu dalam hal ketika panen tiba. Akan tetapi seiring berjalannya waktu sistem gotong royong itu sudah mulai pudar."(Hasil wawancara Kamis, 01 Agustus 2019).

Selain itu, bapak Dg. Ngaca (40 tahun) yang berprofesi sebagai petani cengkeh juga mengatakan bahwa:

"Kalau sekarang sistem gotong royong tidak lagi terjalin dengan baik atau sudah sangat jarang sekali dilakukan oleh masyarakat yang dulunya kegiatan menanam cengkeh dan memanen cengkeh dilakukan dengan cara bersama-sama dengan cara membantu secara bergiliran seperti dibantu oleh keluarga maupun masyarakat sekitar tapi sekarang sudah sangat jarang lagi sekarang rata-rata hanya dikerjakan oleh pemilik saja bersama dengan istri dan anak-anaknya."(Hasil wawancara, 05 Agustus 2019).

Seperti yang diungkapkan oleh Dg. Baha (45 tahun) yang berprofesi sebagai petani cengkeh yang mengatakan bahwa:

"Kalau sistem gotong royong kalau dahulu sangat terjalin dengan baik dimana kita saling membantu dalam hal ketika panen tiba. Akan tetapi seiring berjalannya waktu sistem gotong royong itu sudah mulai pudar."(Hasil wawancara Kamis, 01 Agustus 2019).

Pekerjaan menanam dan memanen cengkeh sekarang sudah jarang dilakukan secara bersama dengan adanya bantuan dari masyarakat, yang membuat para petani dan masyarakat sudah mulai bersifat individualis dimana mereka sibuk dengan aktivitas mereka masing-masing. Seperti halnya dalam kehidupan 
ekonominya yang semula sebagian besar masyarakat desa bekerja pada sektor pertanian cengkeh, setelah masuknya masa industrialisasi, semangat gotong royong masyarakat berkurang, hal ini disebabkan karena masyarakat sekarang cenderung besifat individualistis. Seiring dengan perkembangannya, masyarakat sekarang lebih sibuk dengan pekerjaannya untuk memenuhi tuntutan hidup yang semakin mendesak. Hal ini yang menyebabkan kegiatan gotong royong semakin ditinggalkan. Akhirnya berdasarkan dari kondisi tersebut maka budaya gotong royong pada masyarakat mulai memudar yang dapat dimaknai sebagai sebuah keprihatinan yang sangat mendalam.

Berdasarkan hasil penelitian tersebut, peneliti dapat menyimpulkan bahwa masyarakat desa Rappolemba sejak dulu memiliki tradisi atau rasa solidaritas yang tinggi diantara mereka akan tetapi seiring berjalannya waktu solidaritas sesame mereka mulai berkurang dimana system gotong royong sudah sangat jarang diterapkan atau diberlakukan bagi para petani cengkeh maupun masyarakat sekitar dikarenakan sudah adanya rasa individualis diantara mereka sehingga proses penananaman dan panen cengkeh itu sekarang hanya dilakukan oleh pemilik, istri dan anak mereka saja.

\section{b. Sistem upah}

Pudarnya tingkat solidaritas sosial masyarakat di Desa Rappolemba Kecamatan Tompobulu Kabupaten Gowa, perlahan budaya gotong royong yang sering dilakukan oleh masyarakat Desa Rappolemba mulai memudar dan tergantikan oleh sistem upah di karenakan kebutuhan hidup yang semakin tinggi. Selain itu masyarakat lain yang tidak bekerja atau memiliki kebun cengkeh mereka ikut tertarik menjadi buruh tani dengan harapan adanya upah yang dihasilkan sebagai buruh maka akan ikut membantu memenuhi kebutuhan hidup sehari-hari. Hal ini berdasarkan dengan apa yang disampaikan oleh Dg. Baha (45 tahun) sebagai seorang petani cengkeh mengatakan bahwa:

"Pudarnya sistem gotong royong ke sistem upah dikarenakan adanya kesibukan masing-masing serta karena rendahnya tingkat ekonomi warga sehingga mereka lebih mengharapkan di beri upah disbanding dengan menyumbang tenaganya tanpa diberi upah dikarenakan dengan adanya upah yang didapatkan sehingga akan menambah atau meringankan sedikit biaya perekonomiannya."(Hasil wawancara Kamis, 01 Agustus 2019).

Selain itu, Dg. Hasin (52 tahun) yang berprofesi sebagai petani cengkeh mengungkapkan bahwa:

"Penyebabnya karena sekarang macam-macam jenis kebutuhan ekonomi atau rumah tangga sudah semakin mahal sehingga memaksa masyarakat untuk menghasilkan uang yang lebih dengan memakai tenaga yang bisa menghasilkan uang bukan lagi membantu melakukan pekerjaan dengan modal keringat sehingga menuntut juga para petani cengkeh yang memiliki kebun cengkeh yang luas untuk mempekerjaan orang dengan cara di beri upah sesuai dengan kesepakatan."(Hasil wawancara Senin, 05 Agustus 2019).

Diperkuat oleh pernyataan Hal ini juga disampaikan oleh bapak Dg. Ngaca (40 tahun) yang berprofesi sebagai petani cengkeh mengatakan bahwa:

"Terjadinya pergeseran sistem gotong royong dikarenakan kebutuhan masyarakat yang beragam atau banyak sehingga mereka menuntut 
adanya sistem upah yang bisa digunakan untuk menutupi kehidupan ekonomi dibandingkan dengan timbal balik bayar tenaga. Dimana dengan kehidupan ekonomi yang sangat meningkat sehingga saling ketergantungan satu sama lain mulai berkurang sehingga dalam bidang pertanian cengkeh sistem gotong royong diganti dengan sistem upah bukan keringat lagi."(Hasil wawancara Senin, 05 Agustus).

Sejak dulu, sistem gotong royong merupakan tradisi yang sangat sering diberlakukan oleh masyarakat dalam hal pekerjaan dimana kebutuhan ekonomi masih mencukupi atau dalam hal harga yang masih bisa dijangkau akan tetapi lambat laun dengan semakin melonjaknya harga barang-barang serta semakin sedikitnya nilai mata uang membuat hal tersebut mulai memudar atau bergeser ke sistem upah agar yang dianggap dapat sedikit membantu atau menambah pemasukan keuangan.

Berdasarkan hasil yang didapatkan dari beberapa informan, maka peneliti menyimpulkan bahwa pudarnya sistem gotong royong dimasyarakat petani cengkeh di desa Rappolembba yang menyebabkan mereka beralih ke sistem upah dikarenakan adanya tuntutan kepentingan kehidupan sosial yang tertuju kepada bagaiamana cara agar mereka bisa menambah atau memenuhi sedikit keperluan atau kebutuhan ekonomi mereka sehingga mau tidak mau mereka yang dulunya memrikan bantuan dengan tenaga yang berupa keringat sekarang setiap tenaga yang mereka keluarkan mereka mengharapkan upah sehingga hal tersebut juga menuntut para petani cengkeh yang memiliki kebun atau lahan cengkeh yang luas untuk mempekerjakan buruh atau pekerja dalam hal membantu pekerjaan mereka dengan cara memberi upah sesuai dengan seberapa besar tenaga yang mereka keluarkan.

\section{Dampak Dari Perubahan Solidaritas Sosial Petani Cengkeh di Desa Rappolemba Kecamatan Tompobulu Kabupaten Gowa.}

\section{a. Dampak Positif}

\section{Memberikan Lapangan Kerja}

Adanya perubahan solidaritas sosial bagi masyarakat Desa Rappolemba Kecamatan Tompobulu Kabupaten Gowa yang berdampak pada pudarnya system gotong royong yang beralih ke sistem upah tentunya memberikan beberapa dampak salah satu diantaranya yaitu dampak positif yang dirasakan oleh masyarakat desa maupun para petani cengkeh di desa tersebut. Seperti yang disampaikan oleh oleh Dg. Mada (45 tahun) sebagai seorang warga desa Rappolemba yang berprofesi sebagai sopir mobil mengatakan bahwa:

"Dengan adanya petani cengkeh didesa ini sangat membantu masyarakat dalam hal memberikan sedikit peluang kerja terhadap masyarakat yang membutuhkan tambahan ekonomi serta mempekerjakan pemuda desa yang tidak memiliki pekerjaan."(Hasil wawancara Rabu, 28 Agustus 2019).

Sementara Dg. Mangsya (32 tahun) sebagai salah satu warga desa Rappolemba yang berprofesi sebagai buruh juga mengatakan bahwa:

"Adanya petani cengkeh membantu memberikan pekerjaan bagi orang kampung dan kebun yang dulunya tidak pernah ditanami apa-apa atau yang tidak terawat bisa difungsikan 
kembali dengan ditanami pohon cengkeh yang dapat menghasilkan uang. Perubahan dalam sistem upah dapat mengurangi pengangguran serta ada yang namanya pembagian kerja dalam memanen cengkeh. Sehingga memberikan sedikit pekerjaan bagi warga desa yang tidak memiliki pekerjaan"(Hasil wawancara Rabu, 02 September 2019).

Pernyataan ini diperkuat oleh Kepala desa Rappolemba Harim Dg. Tompo, SH. (42 tahun) juga mengungkapkan bahwa:

"Dengan banyaknya masyarakat desa yang menanam cengkeh maka juga akan ikut meningkatkan kesejahteraan taraf hidup warga selain itu juga menekan jumlah angka pengangguran di Desa dikarenakan petani yang memeiliki kebun cengkeh yang banyak atau luas maka ketika panen tiba maka akan memerlukan tenaga orang lain yang akan bekerja dengan cara di upah. Selain hal tersebut juga membantu dalam memberikan sedikit pekerjaan bagi warga desa yang tidak memiliki pekerjaan sama sekali agar dapat membantu memenuhi kebutuhan ekonominya."(Hasil wawancara Rabu, 31 Juli 2019).

Bergesernya sistem gotong royong ke sistem upah membawa pengaruh positif bagi masyarakat desa dalam hal memberikan sedikit pekerjaan kepada warga desa serta ikut serta dalam membantu memenuhi kebutuhan ekonomi para kerjanya selain itu dengan banyaknya masyarakat yang menanan cengkeh juga ikut serta dalam mensejahterahkan taraf hidup masyarakat desa.

Berdasarkan informasi yang diperoleh dari informan, maka peneliti beranggapan bahwa dengan banyaknya masyarakat desa Rappolemba yang memiliki lahan cengkeh yang luas maupun masyarakat desa yang menanam cengkeh dengan lahan seadanya dimana dengan menerapkan sistem upah maka akan sedikit memberikan peluang bagi masyarakat desa yang lainnya yang membutuhkan tambahan pekerjaan atau bahkan bagi mereka yang sama sekali tidak memiliki pekerjaan baik itu para pemuda-pemudi desa bahkan sampai ibu rumah tangga bisa turut serta dalam hal menjadi buruh atau pekerja dalam bidang tanaman cengkeh.

\section{Meningkatkan Perekonomian}

Salah satau dampak positif dari adanya perubahan solidaritas masyarakat petani cengkeh dalam bidang menerapkan sistem upah bagi para pekerja memberikan sedikit manfaat bagi masyarakat desa atau pekerja dalam hal untuk menambah sedikit perekonomian mereka baik dalam jangka panjang panjang maupun pendek. Dg. Mada (45 tahun) salah satu warga desa yang berprofesi sebagai sopir mobil mengatakan bahwa:

"Salah satu diantaranya yaitu dengan banyaknya orang yang bertani cengkeh sangat memberikan pengaruh atau perubahan yang signifikan terhadap sistem perekonomian warga karena dapat membantu menutupi kebutuhan sehari-hari, biaya sekolah anak dan kebutuhan yang lain dan sebagai sumber mata pencaharian masyarakat desa juga dapat menunjang atau membantu taraf hidup masyarakat kedepanya."(Hasil wawancara 28 Agustus 2019).

Banyaknya masyarakat desa yang memiliki kebun cengkeh yang luas membawa keuntungan tersendiri bagi masyarakat desa yang tidak memiliki kebun cengkeh atau pekerjaan sehingga dengan adanya upah membuat masyarakat desa turut serta dalam 
beralih ke sistem upah memberikan dampak negatif yaitu menurunnya nilai kebersamaan dan kebiasaan bagi sesama petani cengkeh maupun dengan masyarakat desa yang lain. Hal tersebut diakibatkan karena sistem gotong royong yang sebelumnya sangat kental dan kuat terjalin kini mulai sedikit dihilangkan dan digantikan dengan sistem upah yang membuat masyarakat semakin jauh sehingga nilai kebersamaan dan kebiasan mereka pun yang sebelumnya terjalin dengan baik sudah mulai berkurang. Padahal dengan adanya solidaritas masyarakat yang tinggi membuat kita menjadi lebih bisa mengerti keadaan sesama warga yang bisa disalurkan dengan cara tolong menolong.

\section{KESIMPULAN}

Pudarnya sistem gotong royong di Desa Rappolemba Kecamatan Tompobulu dikarenakan kurang efektifnya keikutsertaan masyarakat desa khususnya petani cengkeh dalam bergotong royong sehingga menyebabkan kebiasaan bantu membantu oleh para petani dan masyarakat sekitar beralih ke cara yang individualis. Adanya penerapan sistem upah mengurangi tingkat solidaritas dalam masyarakat dimana nilai kerjasama bisa diganti dengan sesuatu yang bernilai. Adanya sistem upah dianggap lebih menguntungkan sehingga lambat laun hal tersebut mulai memudarkan kebudayaan gotong royong yang mengandalkan kerjasama tanpa imbalan.

Adanya perubahan solidaritas sosial petani cengkeh di Desa Rappolemba Kecamatan Tompobulu Kabupaten Gowa memberikan dampak positif dan negative bagi petani cengkeh maupun masyarakat sekitar. Adapun dampak positif dengan adanya penerapan sistem upah memberikan sedikit pekerjaan bagi pemud-pemudi desa yang memerlukan pekerjaan atau bagi mereka yang tidak memiliki pekerjaan sama sekali. Selain itu dengan adanya upah tersebut juga ikut dalam membantu memenuhi ketuhan ekonomi para pekerja atau buruh cengkeh. Adapun dampak negative dari adanya sistem upah tersebut yaitu nilai kebersamaan dan kebiasaan yang selama ini terjalin dengan masyarakat mulai berkurang sehingga mereka mulai meninggalkan tradisi mereka yaitu gotong royong.

\section{DAFTAR PUSTAKA}

Bachtiar, Wardi. 2006. Sosiologi Klasik. Bandung: Remaja Rosdakarya.

Fuady, Munir. 2001. Hukum Kontrak (Dari Sudut Pandang Hukum Bisnis). Bandung: Citra Aditya Bakti.

Iqbal, Hasan. 2002. Pokok-pokok Materi Metodologi Penelitian dan Aplikasinya. Bogor: Ghalia Indonesia.

Johnson, DP. 1990. Teori Sosiologi Klasik dan Modern II. Gramedia, Jakarta.

Lawang, Robert M.Z. 1985. Pengantar Sosiologi. Jakarta: Karunika.

Moleong, L. J. 2010. Metodologi Penelitian Kualitatif. Bandung: Remaja Rosda Karya.

Mead, George H. 1934. Mind, Self, and Society. Chicago:The University of Chicago Press.

Martono, Nanang. 2012. Sosiologi Perubahan Sosial; Perspektif Klasik, Modern, Posmodern, dan Poskolonial. Jakarta: PT Raja Grafindo Persada.

Nasution, Zulkarnain. (2009). Solidaritas Sosial dan Partisipasi Masyarakat Desa Transisi. Malang: UMM Press

Roucek, Joseph S. Warren, Roland L. 1984. Pengantar Sosiologi. Jakarta: Bina Aksara.

Senoaji, Gunggung. 2010. Dinamika Sosial dan Budaya Masyarakat Baduy dalam Mengelola Hutan dan Lingkungan. Jurnal Bumi Lestari, Vol. 10, No.2, Hal. 302-310.

Santoso, Slamet. 2009. Dinamika Kelompok; Edisi Revisi cetakan ke III. Jakarta: Bumi Aksara. 
Soekanto, Soerjono. 2006. Sosiologi Suatu Pengantar. Jakarta: Raja Grafindo Persada.

Suprihatin, Ira. (2014). Perubahan Perilaku Bergotong Royong Masyarakat Sekitar Perusahaan Tambang Batubara di Desa Mulawarman Kecamatan Tenggarong Seberang. E-journal Sosialtri. Vol. (3). Hlm. 5.

Soemantri, Gumilar Rusliwa. 2005. "Memahami Metode Kualitatif". Jurnal Makara,Sosial Humaniora, No. 2, Vol. 9, 2005. HIm 57-65.

Zulkarnain, Wildan. 2013. Dinamika Kelompok; Latihan Kepemimpinan Pendidikan. Jakarta: Bumi Aksara.

\section{Sumber Jurnal}

Hidayat, Rahmat. 2016. Solidaritas Sosial Masyarakat Petani di Kelurahan Bontolerung Kecamatan Tinggimoncong Kabupaten Gowa. file://C:/Users/FAJAR\%20COMP/ Downloads/Documents/RAHMAT\% 20HIDAYAT_opt.pdf. 29 Mei 2019.

Mda, Safril. 2015. Perubahan Sosial dan Budaya Masyarakat Petani Kakao di Kecamatan Lilirilau Kabupaten Soppeng. Jurnal Masyarakat dan Kebudayaan Politik. Vol.25.Nomor 1:8-14.

C:/Users/Fajar\%20COMP/Downloa ds/Documents/02\%20MKP\%20Mu hammadiyah,\%20edit\%20safril\%20 mda.pdf. 29 Mei 2019.

Chairy, Ummul. 2016. Assitulungeng (Study tentang Nilai Solidaritas Petani di Desa Tonrong Lempong Kecamatan Bola Kabupaten Wajo). C://Users/FAJAR\%20COMP/Downl oads/Documents/Ummul\%20Chair y.pdf. 18 Juni 2019.

Lestari, Slamet. 2015. Pergeseran nilai gotong royong dalam pengolahan lahan pertanian desa pulung kencana. https://media.neliti.com/media/pu blications/252037-pergeseran-nilai- gotong-royong-dalam-pen9a862007.pdf

https://www.academia.edu/34749013/K onsep_Dasar_dan_Teori_Perubahan_ Sosial.rtf

http://samun88.blogspot.com/2016/04/t eori-fungsionalis-functionalisttheory.html

https://eprints.uny.ac.id/8856/3/BAB\%2 02\%20-\%2006413244029.pdf

https:/www.wikiwand.com/id/Tompobul u_Gowa. 